\title{
HISTORY AND DRAMATIC IMAGINATION IN AHMED YERIMA'S ATTAHIRU
}

\author{
Rasheedah Liman \\ Ahmadu Bello University Zaria, Nigeria
}

\begin{abstract}
The thematic concerns of some dramatic creations among postcolonial African playwrights often bear witness to moments of ideological encounter between the colonizer and the colonized. The dramatic space also serves as an avenue where the encounter is revisited, reassessed, or challenged. In this way, Attahiru, a play by Ahmed Yerima introduces a new perspective that insists on the presentation of a version of history that is different from the dominant position of colonial power. On the one hand, colonial accounts portrayed Sultan Attahiru, the Sultan of the Sokoto Caliphate during the late 19th century, as an element of destabilization and a threat to the power and order established by the British colonialists, particularly in the northern protectorate. On the other hand, through narrative technique, Ahmed Yerima illustrates political resistance and the discourses of tradition and modernity, conflicts of religion and culture and the question of identity and power. The historical figure Attahiru is revived as a resistance fighter, a religious figure, a revolutionary leader who is sensitive to power and the demands of his people. However, the major problem arising from a comparison between the historical figure of Attahiru and the dramatic character remains that of the credibility of their representations. The question then is, can narrative technique in a dramatic text give credence to a dramatic character, represented in the synchronic present over the historic one that is constructed by a method aspiring to be objective and rigorous? This paper attempts to answer this question through the textual analysis of the play text against the backdrop of various historical accounts.
\end{abstract}

KEYWORDS: AHMED YERIMA, DRAMA, SOKOTO CALIPHATE, HISTORY, MEMORY

\section{Introduction}

The colonial history of Nigeria like many other western colonies in Africa is often defined in terms of dominance and resistance. These factors are evident in the ancient kingdom of Benin, the Borno Empire and also the Sokoto Caliphate of northern Nigeria. The idea of resistance has in one way or the other contributed substantially to shaping the history of Nigeria as a nation. These historical experiences have been creatively engaged through dramatic forms. History as source material for dramatic presentation helps to bring immediate attention to subjects that might have been forgotten. While some scholars have argued that "history as material for dramatic text, is often distorted for aesthetic reasons" (Julius-Adeoye 2013:78), others have highlighted how historical plays serve "as a prism through which the present can be fruitfully apprehended" (Abubakar, 2014:1).

Furthermore, "though drama may be the specific mode of fiction represented in performance, it could also be the documentation of a true-life account..." (Julius-Adeoye, 
2013:78). Instances of the function of drama in bringing history to the fore finds support in the nature of popular Nigerian historical plays that have reflected and represented the past, in all its colonial, cultural and political complexities. This can easily be seen in works of playwrights like Wole Soyinka, Femi Osofisan and Ola Rotimi. Another writer whose early works were based on adaptation of historical materials is Ahmed Yerima. Yerima wrote a number of plays such as The Trials of Oba Ovonranwen, The Bishop and the Soul with thank you Lord, Kaffir's Last Games, The Silent Gods and Orisha Ibeji have drawn from historical materials. In some of these plays, historical events, such as the British expeditions against Benin City (Oba Ovonranwen), the deification of twins in Yorubaland (Orisha Ibeji) and the conquest of the Sokoto Caliphate narrated in the play Attahiru, history has been the source material. And all these historical events are adapted and used in various ways to highlight issues that are of contemporary social relevance. Adaptation of historical materials is a feature of theatrical and dramatic practice in Nigeria. Indeed, historical personages have also been deployed in the service of adaptation by Nigerian dramatists. What may be called the dramatization of history "is often a conscious attempt by Nigerian, nay African, dramatists to - recapture the past, use it as an analytical tool to reflect on the present, and to preserve it for posterity" (Adeyemi, 2006: 17). Moreover, it is frequently through drama that the past has come to be a symbolic resource of the creative imagination of African people.

Scholars have described the play Attahiru, which is the focus of this paper, as an historical play that tells the history of Sokoto Caliphate and Northern Nigeria during the colonial period. Julius-Adeoye (2013:11) states that the historical play Attahiru chronicles the fate of Sultan Attahiru of Sokoto at the hands of the British colonialists in the early twentieth century. Lord Frederick Lugard deposed Attahiru as ruler of the Caliphate in 1903 through military force, and the play re-creates the political situation within the Caliphate on the eve of the conquest. It reenacts "the heroism of Attahiru who, within his short reign of six months, left an indelible mark in the course of history by leading the Muslim's resistance against British imperialism" (Effioks, 2007:127).

In Attahiru, first published in 1999, Yerima's concern is with the history of the Sokoto Caliphate. The play is a dramatization of the heroic times of Sultan Attahiru and his warriors who fought and lost their lives for the freedom and integrity of their people at the battle of Burmi in 1903. In the Author's Note, Yerima explains that it was necessary to write the play because of the "need to reconstruct the past and subject it to a process of selfcriticism, while empowering even the sometimes historical contradictions presented with illusion, immediacy and theatrical magic" (Yerima, 1999: 6) However, the major problem arising from a comparison between the historical figure of Attahiru and the dramatic character remains that of the credibility of their presentations. The questions then is, can the technique in a dramatic text give credence to a dramatic character, over the historic one that is constructed by a method aspiring to be objective and rigorous? This paper attempts to answer this question through the textual analysis of the play text against the background of various historical accounts. It may be helpful at this point to give a brief background of the historical figure, Muhammad Attahiru before diving into other arguments of the paper. 


\section{The Sokoto Caliphate and the Struggles of Attahiru}

The Sokoto Caliphate was an independent Islamic Caliphate in West Africa. Usman Dan Fodio founded the Caliphate in 1804 as a result of the jihad that was led mainly by the Fulani ethnic group (Falola, 1985:276). Dan Fodio was proclaimed Amir al Mu'minin, defender of the faithful. He then declared a number of his followers the flag bearers of the jihad, as they created the early political structures of the empire. From 1808 until 1830s, the Sokoto Caliphate expanded gradually by annexing the plains to the west and key parts of Yorubaland. It became one of the largest states in Africa, stretching from modern-day Burkina Faso to Cameroon, including most of Northern Nigeria and Niger Republic. At its height, the Caliphate linked over 30 different emirates and was one of the most significant empires in Africa in the nineteenth century. The religious and political structures of the Caliphate were organized with the Sultan of Sokoto ruling from the city of Sokoto, a territory in the present north west part of Nigeria. The Hausa Kingdoms prior to the Caliphate had been run largely through hereditary succession. The early rulers of the Sokoto Caliphate i.e Dan Fodio and Muhammad Bello however, abolished this hereditary system, replacing it with the process whereby leaders were appointed by virtue of their Islamic scholarship and moral standing. The leaders of the Caliphate were called Emirs, and were appointed by the Sultan. They travelled annually to declare their allegiance and deliver taxes collected in the form of crops, cowry shells and slaves. Slavery remained a large part of the economy, although its operations had changed fundamentally with the end of the legal Atlantic slave trade imposed by Great Britain and the United States. Slaves were gained only through raiding and not through the market as operated earlier in West Africa (Usman, 1995:17).

When a Sultan dies or retires from the office, an appointment council made up of the various kingmakers would select a replacement. Direct lines of succession were largely not followed for Sultan, although each Sultan must be a direct descendant of Dan Fodio. There were multiple crises that arose between the Sokoto Caliphate and many of the emirates, notably the Adamawa and Kano emirates. Scholars such as Last (1977) report that these conflicts were calmed, and often were settled through the mechanisms of the common Sufi and Tariqa Islamic brotherhoods. Islamic scholarship was the crucial aspect of the Caliphate right from its founding days. Sultan Usman dan Fodio, Sultan Muhammad Bello, Abdullahi dan Fodio, Sultan Abu Bakr Atiku and Nana Asma'u devoted much time to historical chronicles, Islamic studies and poetry. The scholarship of Nana Asma'u is particularly intriguing given the patriarchal nature of the $19^{\text {th }}$ century Sokoto Caliphate. Historical texts and oral narrations have revealed very little about the early life of $\mathrm{Mu}$ hammad Attahiru I. This may not be unconnected with the frequent movements and immigration prevalent in the Caliphate at the time of his birth. According to Last.

The Muslim leadership was not living in one place, Macina, Marate, Magarri, Degel, Gudu, Gwandu, Sifawa, Sokoto, Wurno, Silame, Danchadi, Chimmola and Ribat centres could have been possible places at which most of the second and the third generations of the Jihad leaders including Muhammad Atahiru I, were born (Last, 1977:29). 
Other historical records reveal that Muhammad Attahiru I may have been born at Chimmola or Gwadabawa. The problem of the preservation of the early life of eminent personalities in the Sokoto Caliphate has created a serious gap in scholarship. For example, very little is referenced about their childhood, peer group, school attended, teachers who taught them etc. Ironically, education (knowledge in general) was reported to be one of the major conditions for the appointment of the Amir al Muminin to lead the Caliphate. Historical accounts of the Sokoto Caliphate, particularly concerning Sultan Muhammad Attahiru by scholars such as Kani and Gandi (1991), Ahmed (1984), Last (1964), AlMasri (1976), Paden (1986), Ikime (1977) and Adeleye (1968), corroborated the fact that he was installed as the $12^{\text {th }}$ Sultan of Sokoto in October 1902 after the death of his predecessor Sultan Abdul Rahman. He was the son of Ahmed bn dan Fodio and the grandson of Abubakar Atiku bn dan Fodio. Attahiru was described as "a man of great integrity and pride who took his responsibilities seriously. He was often surrounded by loyal men who revered him as the Commander of the faithful" (Ikime, 1977: 202). Immediately after his ascension to the throne, Attahiru was confronted with challenges to his authority by the British conquerors. In order to properly highlight the dilemma of Attahiru, it will be essential to also understand the situation in Sokoto prior to his ascension.

The last decade of the $19^{\text {th }}$ century was one of increased European activity in the Caliphate. French activities, according to Ikime (1977:202), including their conquest of the Tukolo Empire in 1889-1895, the race between them and the British to Nikki in the struggle over Borgu (1894) as well as renewed German efforts at digging themselves in at Gwandu (1895) "had the effect of making Sokoto and Gwandu harden their attitude towards the Europeans". By 1896 the policy of the Royal Niger Company was to seek to consolidate Sokoto by posing as the less dangerous of the European powers when in 1897 the company's conquest of Nupeland and Ilorin became a stark reality, the Caliphate reacted by refusing to recognize the conquest.

Lugard's next act was to attack and conquer Kontagora, Bida and Yola in 1901 and Bauchi in February 1902. All of these were places, which own loyalty to the Caliphate, and their rulers paid annual tributes to Sokoto. It is therefore easy to see what their conquest meant to the Caliphate in Sokoto. However, even after the conquest of these various cities by the British they still pay homage and tribute to Sokoto. Lugard was worried by this development. According to Ikime (1977:201)

it showed that these Emirates did not yet regard him (Lugard) as the final authority in the land. This made him even more determined to bring Sokoto directly under British control. In 1902, Lord Frederick Lugard wrote two letters to Attahiru, telling him about the conquest of Kontagora, Bida, Bauchi, Yola and a number of other Emirates. Attahiru I also wrote to Lugard, the famous letter in which he said that between him and the British "there could be only one kind of relationship- War.

Thus, Lugard began to prepare for war against Sokoto by stationing British troops at Argungu and Gwandu. This was the situation till the end of 1902 (Ikime, 1977:250). 
The internal political situation in Sokoto also deserves some attention. Sultan AbdulRahman who Lugard initially disagreed with in 1900, passed away in October 1902. After Abdul-Rahman's death there were some internal struggles for succession. When Attahiru was installed, some groups within the Sokoto Caliphate were unwilling to give up their rights to the throne. At the same time "there was no guarantee therefore that in the face of this external threat, Sokoto could put up a united front" (Tiberderana (1974) quoted in Abdullahi (1990:9). As with his predecessor, Attahiru was unwilling to surrender his sovereign powers to the British. Johnston (1967) cited in Abdullahi (1990:11) states that

This is clear from his refusal to accept Colonel Morland's ultimatum of February 1903 to capitulate to the British without fighting or to face war with all its implications. Attahiru I however, evidently felt that it was impossible for him to surrender to a Christian power would amount to breach of Faith. More so, there was no consensus amongst members of the Caliphate

Three different opinions were said to have appeared within the Sokoto Caliphate. The first group, according to Abdullahi (1990: 12), advised that Sokoto should make peace with the British as Katsina had done at the last minute. The group argued that Sokoto could not hope to fight successfully against the British. Another group was for war despite the fact that all who had so far fought against the British had been defeated. And the third group to which the Sultan belonged, advised that people should migrate from Sokoto rather than submit to being ruled by the infidels. But no group succeeded in convincing all the others to migrate. There was thus no agreement on how to prepare against the British (Ikime, Abdullahi, Tiberderana)

Thereafter, "their verdict was that, it was unthinkable for the Commander of the faithful to submit voluntarily to a Christian power and that he must fight and if necessary die. Attahiru accepted their judgment" (Ikime, 1977: 252). The clash between Attahiru of Sokoto and the British Empire represented by lord Lugard took place on the morning of $15^{\text {th }}$ March 1903. Although Sokoto was defeated, a formidable and heroic resistance was reported to have taken place between the Caliphate and the British. It is worth noting that Attahiru was prepared to fight up to the last minute. Reports have it that,

As soon as he realized that there was no hope of coming to grips with the British. The Marafa Maiturare galloped over from his position on the right to urge the Sultan to abandon the battle. Beware he said, "let the fire be extinguished while you hold it" by this he meant that if the Sultan resisted in a hopeless struggle he might be guilty of destroying the whole heritage and posterity of the Fulani. But the Sultan is made of sterner stuff than his brother. 'Do you think' he demanded angrily. 'that this is my first battle'? (Ikime, 1977:205).

Another encounter, which was recorded on the battlefield, was between the Sultan and the Waziri. The report goes thus,

The Marafa, who had already two horses, was now wounded and one household slave killed. At this point the Waziri Bukhari intervened and told the Sultan that from 
then on the blood of all those who fell in the battle would be on his head. At this the Fulani forces began to melt away and he at last allowed his horse to be led from the field. It was the end not only of the battle but also virtually of an epoch. There remained only the last act, which the unhappy Attahiru had to play out the tragic part of the fate that had been assigned to him (Ikime, 1977:252).

Afterwards, the decision of a large number of the Sultanate was to go on Hijrah-emigration from the "infidels". Thus by the time the British marched victoriously into Sokoto the town was almost deserted. The Waziri who earlier had had a different opinion reportedly reminded the people about Shaikh Uthman Dan Fodio's permission for Muslims to make friends with unbelievers when the Muslims were forced to live in fear of such unbelievers and could not successfully fight against them. The only condition that Uthman Dan fodio attached to this permission was that this forced friendship was not to be deep. The Muslims had to wait until they were strong enough to fight back and regain their independence. In this way Waziri Bukhari led a large crowd back into Sokoto and surrendered to the British. Thus Attahiru II was appointed the new leader and was named the new Sultan. Abdullahi (1990: 13) states that

Despite the surrender, the Britsh felt uneasy about the notion of Hijrah. More so that the people's royalty was still with Attahiru I because they felt that Attahiru II was a puppet and a creation of the British. The people saw the flight of Attahiru I as a continuation of the fight against the British. They saw it as an attempt to uphold the teachings of Islam, which forbade Muslims to submit to unbelievers. Indeed the Hijrah of Attahiru I was a direct challenge to all those who had accepted the British rule. Therefore, Emirs and people alike responded to this new form of challenge either by joining the Sultan in Hijrah or by sending him assistance in form of food, clothing and other necessities.

The next major event was the battle of Burmi, 13 ${ }^{\text {th }}$ May 1903 when Attahiru was on his way to Gwani. At the end of this battle, the British force accepted defeat and Captain Sword had to retreat at night. According to the British record of events, not only was this, the first defeat suffered by the British since they began the conquest of the Sokoto Caliphate, the casualties were also the heaviest (Ikime, 1977:207). As for Attahiru I, two months of flight had begun to tell on his followers. Many had returned to their homes and families; many had died in battle against the British. After the first battle of Burmi, Attahiru moved into town and it was there that he made his final stand against the British. The second battle was reported to have been fiercer than the first. According to the report from Ikime (1977) "the battle at Burmi went on from 11:00 in the morning right up to 6:00 in the evening. It was the largest battle in the British conquest of the Sokoto Caliphate". Further details of the final battle are reported thus

On 27 July, a little before noon, the British forces appeared under the walls of Burmi and the final battle began. It was proved easily the toughest and bloodiest of the whole campaign. The die-hards of Burmi fought with fanatical courage and devotion 
against the infinitely superior weapons of their enemies. Some deliberately courted death. Others lashed themselves together so that they should not be tempted to try to escape but would die together. When the fighting began Attahiru went to the mosque. He remained there praying until he heard that the gates had been breached and then he emerged and went down to the walls. He was on foot, unarmed, and his intention was not to fight but to go out and meet his fate. It was a gesture not less noble than Gordon's at Khartoum. Death came to him with merciful swiftness for when he was within a stone's throw of the southern wall he was shot through the head. Two of his sons died by his side and ninety of his followers, showing the same devotion as the bodyguards of Hayatu and Zubeiru chose to perish with him rather than save themselves in flight (Tiberderana, 1974)

The views and opinions regarding the resistance against British domination, led by Muhammad Attahiru vary depending on the religious, cultural and political ideologies of those expressing the views and opinions. While the historical accounts by scholars such as P.K Tiberderana (1974), Ikime (1977), Last (1977) and Paden (1986) seems to correlate, other views such as that of Abdullahi (1990), E.J. Arnett (1972), IA.B Balogun (1975), B.O Ahmed (1984) differ from the latter group especially as it relates to the bravery, dignity and fight of Attahiru against the colonialists. For instance, P.K Tiberderana's account (quoted above) of the final battle and eventual death of Muhammad Attahiru states that "He was on foot, unnamed, and his intention was not to fight but to go out and meet his fate". This account differed completely from the account related in Ahmed Yerima's play Attahiru.

\section{Textual Analysis}

The playwright employs fluid and simple dramatic techniques to tell the story of the Sokoto Caliphate. The plot creatively captures the last few months of Sultan Muhammad Attahiru's reign, at the same time, providing the readers with the cultural, social, political and religious dynamics of the Caliphate and its people. Through concrete characterization, action, body movement, stage direction, flashbacks, symbolism, proverbs, humor, metaphor, foreshadowing etc, the playwright is able to present a thematic concern that is in the past, yet relevant to the present. The nobility and heroic acts of defiance of the main characters have not foreclosed the importance of the common personages. Social class, faith and the personalities of the characters are presented through language and dialogue. The characterization of Abbas, Yakubu and Ahmed in the play readily portrays their social class, education and faith. For instance, through use of plain language, the general condition of the poor is captured through Abbas;

ABBAS: I must find a suitable place where the coins will reach me when they throw them. A place where the rich will see my plunked out eyes as they are about to bite into their food. Sometimes it works so well, I even get a bonus, their conscience gets so touched I get their whole plate of food. Allah never forgets His own...I tell you... He never forgets. 
The playwright has from the beginning of the play established the dominating and destructive nature of the White colonialists within the Sokoto emirates. Three characters, Ahmed, the seller of date palms, Yakubu, the seller of Islamic books and Abbas, a blind beggar, are at the entrance gate to a mosque, exchanging banter and discussing what has happened to Abbas, who is robbed by a thief disguised as a fat woman. It is from their discussion that we learn that the former Caliph, Caliph Abdul-Rahman, has died and a new Caliph is to be named. It is also from their discussions that we learn of the military conquests of Kano, Kontagora, Yola, Zaria and the impending invasion of Sokoto.

ABBAS: He must have...Haa Allah...All that money. Our uncle had died a rich man. The war in Kano with the whiteman has been a great loss to my family. We lost all of his camels and load. His shop was burnt. And we hear that the king of the whitemen Lugga, wants to come to Sokoto.

AHMED: A thousand curses on his white evil soul. Did you hear what they said he did to Kontagora, Bida and Yola? That man is just hungry for Muslim blood, and by Allah, he shall be shamed in Sokoto.... (pp 16-17).

The dialogue between these characters also buttress the need for the Caliphate to select a strong leader who will protect the people and the religion of Islam against the intruding and undermining behaviour of the white colonialists.

YAKUBU: Look at them. First, I hear they came as friend to your own land, asking for a place to stay. Then before long, they say you a pagan for worshiping Allah and that you will not see heaven for having more than one wife. And that it is evil in the eye of Annabi Isah Alaihi Salam to....

ABBAS: Allah be praised! Apart from his colour and his long nose, then we are one. We need not be afraid of him at all.

YAKUBU: That is why we need a strong-willed man as Caliph. A man chosen by the light of Allah, who will carry the flag of Islam past the whiteman's threat. A man who will stand shoulder to shoulder and eye ball to eye ball with the whiteman.... (pp.16,17)

When Caliph Muhammad Attahiru is sworn in, the first task he is confronted with is the restoration of peace and the impending visit to Sokoto by the British expedition team. The times were uncertain, and the new Caliph alluded to this in his first speech to the people on his ascension to the throne:

CALIPH: I am becoming the Caliph at a time when the history of our lives is at a delicate balance. At a time when the Whiteman is determined to upset the peace of our lives. But it is too early to dare enemies, or look for one. I shall await their moves. But let us pray for Allah's hand in the matter. Let us pray for peace. Let us pray for our children. Let us pray for the growth of our lives and position in the Islamic world. Thank you all. (p.21) 
A few weeks after his ascension as the Caliph, Attahiru receives a third letter from the colonial government of Lugard, asking for his co-operation in their plan to introduce indirect rule. The letter informs him that the Emirs of Kontagora and Bida have been removed for 'oppressing their people, engaging in slave trade, attacking traders, organizing stealing parties and their crowns taken from them'. He is therefore requested to select 'new and better Muslim leaders and persons in the place of these deposed leaders to rule those territories'. He is also reminded that though the British government is willing to work with him, the 'British soldiers have already established British rule over Muslim lands all over the world.' (p 27)

The letter is not received well with the Caliph and some members of the council. After extensive debates, particularly between Ubandoma who begs for caution and Madawaki who calls for resistance, the Caliphate decide that the emirate should go to war. Thus;

CALIPH: (Gestures to speak, there is complete silence) Great servants of the faith we have heard you all. Friendship is a delicate aspect of human life put there by Allah to test human will. To have a friend, a wise Mallam once told me, you must close one eye, but to keep the friendship going takes sacrifices, so you close both eyes. But can there be friendship between an infidel and a believer?
ALL: No
CALIPH: To this effect, the Waziri must write to him this reply. Tell the infidel that we did not invite him to interfere with our problems. He has his religion and we have ours. (Rises. The whole court rise). As my predecessor Caliph Abdul- Rahman had earlier said, the only relationship that can exist between a believer and an infidel is...war! (pp 32,33).

Representing the colonial administration we find Lord Frederick Lugard afraid of the Caliphate falling into the hands of the French who are stationed nearby. Lugard is also afraid of a Jihad because the 'war never ends'. He voices his fear thus,

LUGARD: I have studied the situation myself. It means that we either fight, and take Sokoto now, or the French would cross the Niger and join Sokoto and thereby cutting us off totally.

Moreover, the British government's desire to control the economic resources of the Sokoto Caliphate is the major reason for their expedition and so sacking of Sokoto, This assertion is corroborated by Lugard within the play in a discussion with Abbass:

LUGARD: This is not a religious war. It is a war of superiority of wills. I have the machine and guns; you have what I need to trade with, so if one of us is stubborn or refused to cooperate then a little nudge is needed. But, you all get excited with your charms, amulets, and religion; you refused to be our friends. It is simple really (p. 56). 
Finally, when the war arrive, the Caliph and his soldiers put up a stiff resistance with the assistance of soldiers from Katsina, Kebbi, Kano, Gombe, and Nupe. After several weeks of fighting, the Caliph and his soldiers are defeated and killed in Burmi. The dialogue between Mai Wurno and Yakubu describes the bravery of Attahiru and his soldiers in the face of a more advanced British military force.

MAI WURNO: And all those brave palace officials. The Madawaki stood by him to the end.

YAKUBU: The Ubandoma, Dan Magaji, Sarkin Kwanni, Dan Waziri, Dan Magaji and the Alkali, all great men.

MAI WURNO: May Allah receive their souls and grant them everlasting peace.

\section{MAI WURNO: Amin!}

YAKUBU: Yet, the greatest moment was when the Caliph fell. As the bullet struck him, he raised up his sword and screamed Allahu-akbar! Allahu-akbar! He was a great man indeed. With the bullets he still cut down two more soldiers, then his Rawani loosened, and his cap fell. He twisted in pain. Holding on to nothing but his guts. Slowly, he started to fall. And as he fell, the Madawaki noticed him, he covered him with his shield, the Ubandoma, all forming a human shield. But the Caliph had fallen, and with his last breath, he screamed again. Amidst the nose of the guns, and the dying men, a gentle breeze blew, and as if we all knew...the Caliph had gone with the passing breeze. That was when the thunderous call came... (pp. 62, 63).

Through Yakubu's speech, the playwright is able to create an inspiring scenario of how the Caliph bravely took his last breath "with the passing breeze" while at the same time highlighting the heroic actions of his followers. But how does one establish levels of historical accuracy from Yerima's play? In other words, are the events, actions, reactions and confrontations presented in this play actual history, a mix of fact and fiction (Faction) or is the play simply a figment of the playwright's imagination? While the play is derived from historical materials, the playwright confirms the tendency to creatively embellish facts in order to entertain. According to Yerima in the Author's note,

For a playwright who wants to write drama out of history, I am able through the materials history provides, to subject it to a process of self-criticism, while empowering even the sometimes-historical contradictions presented with illusion, immediacy and theatrical magic. Some critics have called this process, "Faction"- the art of mixing facts of history with fiction of the mind of the playwright. I call it giving life to the past... to the dead, so that it makes new and immediate meaning to the present.

It would be unrealistic to believe that the dramatization of historical materials should be factual when history itself is often said to be a subjective discipline. "We remember only 
what we wish to remember and how we wish to remember is ours to decide" (Abubakar, 2007:60). A careful reading of the play, according to Abubakar (2007: 61), "reveals that the author might have deliberately recounted the events of the time the way he does for some reasons, and these reasons, which might be said to be subversive in nature are in the spirit of postcolonial literary strategy." Indeed Ahmed Yerima is able to present the social, political and religious agendas related to the issues of colonial conquest and the institutionalization of British rule in Nigeria.

\section{Conclusion}

The dramatic arts and along with its performances in all their shades and nuances do not merely serve to entertain. In the African context they become useful media for the preservation of historical memory. The need for the preservation of history demands that the playwright deploy actual history itself, as source material for dramaturgy. As it is, drama as well as other arts forms is a veritable means of understanding the cultural, religious and socio-political values of society, whether in the past or the present. In the case of Ahmed Yerima, he is able to combine facts with fiction to educate and entertain his audiences. Similarly, the defeat and death of Muhammad Attahiru signifies many things amongst which is the defeat and conquest of a people and their cherished way of life. However, the same history has proved that this conquest did not deflate the pride, faith and culture of the people of Sokoto. Even if things are not as they used to be, Sokoto is still the seat of Caliphate and Hausa-Fulani culture in contemporary Nigeria.

\section{References}

Abdullahi, A.S.S, (1992) "Religious-Cum-Political Contributions of Amir Al-MuMinin Muhammed Attahiru 1", Sokoto: Usmanu Dan Fodiyo University Press.

Abukakar, B (2014) "Dramatization of Northern Nigerian History: Adaptation, Tradition and Personages of Ben Tomoloju's Aminatu Queen of Zazzau, Ahmaed Yerima's Attahiru and Umaru Ladan and Dexter Lyndersay's Shaihu Umar" Unpublished Dissertation in the Department of English and Literary Studies, A. B.U Zaria.

Adeleye, R.A (1968) "The Dilemma of the Wazir" The Place of the Risalat al Wazir ila Ahl 1lm wa alTadabbur in the History of the Conquest of the Sokoto Caliphate, JENS. Vol.IV No 2.

Balogun, I. A.B (1975) The Life and Works of Uthman Dan Fodio, Lagos: Islamic Publication Bureau.

Effiok B U. (2007) "Yerima's Theatre and Nigerian History: The Trials of Oba Ovonramwen and Attahiru." Muse and Mimesis: Critical Perspectives on Ahmed Yerima's Drama. Ed. Gbemisola Adeoti. Ibadan: Spectrum Books.

El-Masri, F.H (1976) (edit \& Trans) Bayan Wujub al-Hijra ala al-ibad, Khartoum: Khartoum University Press.

Falola, T. (1988) Earliest Yoruba Writers, Ibadan: Spectrum.

Finnegan, R. (1970) Oral Literature in Africa, London: Oxford Press.

Julius-Adeoye, R.J, (2013) The Drama of Ahmed Yerima, Leiden: University of Leiden Repository.

Kani, A. M and Gandi, K.A (1991) (edit) State and Society in the Sokoto Caliphate, Sokoto: Usmanu Danfodiyo University.

Ikime O. (1977) Leadership in Nineteenth Century Africa, Longman: London 
Ikime, O. (1977) The Fall of Nigeria: The British Conquest, London: Heinemann.

Jeyifo, B. (ed) (2002) Modern African Drama, New York: W.W Northern \& Inc.

Johnson H.A.S, (1967) The Fulani Empire of Sokoto, London: Oxford University Press.

Last, M. (1977) The Sokoto Caliphate, London: Longman Group Limited.

Lugard, L. (1965) The Dual Mandate in British Tropical Africa, London: Frank Case and Co Ltd.

Osofisan F. (2001) Insidious Treasons: Drama in a Post Colonial State (essays) Ibadan: Opn Ifa Readers.

Paden, J.N (1986) Ahmadu Bello Sardauna of Sokoto: Values and Leadership in Nigeria, Nigeria: Hudahuda Publishing limited.

Tiberderana, P.K. (1974) "The Administration of Sokoto: Gwandu and Argungu Emirates Under British Rule 1900-1946" PhD Thesis, Ibadan.

Tutler, A (1998) "Play Composition", In Grey B. ed. Theatre and Drama: a Practical Approach, Ibadan: Hopes Publications

Uka, K. (1980) Drama and Conscientisation: Reading in African Humanities African Cultural Development (ed). U Kalu, Enugu: Dimension Publishers.

Usman, B.Y (1995) (edited) Studies in the History of Sokoto Caliphate: The Sokoto Seminar Papers, New:York: Third Press Limited

Yerima, A. (1999) Attahiru. Ibadan: Kraftgriots.

Yerima, A. (1999) Author's Note. Attahiru, Ibadan: Spectrum 